\title{
Long-Term Nitrogen and Phosphorus Dynamics in Waters Discharging from Forestry-Drained and Undrained Boreal Peatlands
}

\author{
Mika Nieminen · Sakari Sarkkola • \\ Eliza Maher Hasselquist • Tapani Sallantaus
}

Received: 26 March 2021 / Accepted: 30 July 2021 / Published online: 31 August 2021

(C) The Author(s) 2021, corrected publication 2021

\begin{abstract}
Contradictory results for the long-term evolution of nitrogen and phosphorus concentrations in waters discharging from drained peatland forests need reconciliation. We gathered long-term (1029 years) water quality data from 29 forested catchments, 18 forestry-drained and 11 undrained peatlands. Trend analysis of the nitrogen and phosphorus concentration data indicated variable trends from clearly decreasing to considerably increasing temporal trends. While the variations in phosphorus concentration trends over time did not correlate with any of our explanatory factors, trends in nitrogen concentrations correlated positively with tree stand volume in the catchments and temperature sum. A positive correlation of increasing nitrogen concentrations with temperature sum raises concerns of the future evolution of nitrogen dynamics under a warming climate. Furthermore, the correlation with tree stand volume is troublesome due to the generally accepted policy to tackle the climate crisis by enhancing tree growth.
\end{abstract}

M. Nieminen $(\bowtie) \cdot$ S. Sarkkola

Natural Resources Institute Finland, Latokartanonkaari 9, 00790 Helsinki, Finland

e-mail: mika.nieminen@luke.fi

E. M. Hasselquist

Department of Forest Ecology and Management, Swedish University of Agricultural Sciences, 90183 Umeå, Sweden

T. Sallantaus

Finnish Environment Institute, Latokartanonkaari 11, 00790 Helsinki, Finland
However, future research is still needed to assess which are the actual processes related to stand volume and temperature sum that contribute to increasing TN concentrations.

Keywords Drainage $\cdot$ Forestry $\cdot$ Peatlands · Temporal trends $\cdot$ Water quality

\section{Introduction}

Internationally, around 15 million hectares of peatlands and wetlands were drained for forestry in the temperate and boreal regions, particularly between the 1960s and the late 1980s (Paavilainen \& Päivänen, 1995). Although these peatlands and wetlands have now been under the influence of drainage for a long time, the primary mechanisms controlling their nutrient exports to receiving water courses are still poorly understood.

It was understood for a long time that drainage of peatlands for forestry had only short-term impacts on nutrient and carbon exports (Finér et al., 2010; Heikurainen et al., 1978). It was generally accepted that, even though peatland drainage may considerably increase nutrient and carbon exports during the first few years after treatment, their exports did not significantly differ from undrained peatlands 10-20 years after drainage. Nieminen et al. (2017) revealed, however, that nitrogen and phosphorus concentrations discharging from drained peatlands had not returned to 
undrained levels but were two-to-three times higher even though several decades had elapsed since drainage. Similarly, Nieminen et al. (2020) showed that this persistent legacy effect of drainage may result in many-fold higher nutrient export estimates from drained peatland forests compared with those where its contribution is ignored (Finér et al., 2010).

Furthermore, the results by Nieminen et al. (2017, 2018) and Räike et al. (2019) indicated that nitrogen and phosphorus exports from drained peatland forests may not only be persistently higher than from undrained peatlands, but they may also increase over time since drainage occurred. Nieminen et al. (2017, 2018) showed significantly higher nitrogen and phosphorus concentrations in waters discharging from old peatland drainage areas where several decades had elapsed since drainage compared with more recently drained areas. Similarly, Räike et al. (2019) found increasing trends of nitrogen concentrations in large boreal rivers discharging to the Baltic Sea. The area of drained peatlands in their catchments was the land use factor with the strongest correlation with these increasing trends.

However, the studies on the temporal trends of nutrient concentrations from drained peatland forests are contradictory. Concurrently with the studies reporting increasing trends of nutrients (Nieminen et al., 2017, 2018; Räike et al., 2019), Finér et al. (2021) showed no increase in nitrogen concentrations over time and even decreasing concentrations for phosphorus. As pointed out by Nieminen et al. (2018), these contradictory results may simply be because the temporal trends of nutrients vary in time and space. Decreasing temporal trends may be expected when drained sites are still recovering from the effects of forestry operations, such as forest drainage, fertilization, or harvesting. Increasing trends of organic carbon and organic nutrients may particularly occur due to climatic warming (Laudon et al., 2012; Sarkkola et al., 2009) and recovery from atmospheric sulfate deposition (Monteith et al., 2007; Erlandsson et al., 2008).

Recent studies also suggest increasing trends due to the "greening effect" in northern latitudes, that is, the expansion and maturation of forests in previously treeless or sparsely tree-covered sites, such as the peatlands subjected to forest drainage (Finstad et al., 2016; Škerlep et al., 2019; Nieminen et al., 2021). Increase in forest biomass in mineral soils and peatlands may contribute to increasing organic carbon and nutrient exports, for example, by increasing root exudates and litter inputs into the soil (Straková et al., 2010, 2012). In drained peatlands, increasing forest biomass may contribute to nutrient and carbon exports also indirectly, that is, by increasing evapotranspiration of vegetation, thus resulting in thicker oxidized peat layers in old drained areas with mature tree stands than in recently drained areas (Sarkkola et al., 2010).

Differing temporal trends of nutrients in different studies may also be related to different geographic locations of study sites. Given that peat decomposition is the main source of nutrients in drained peatlands (Laurén et al., 2021), variations in temporal nutrient export trends may be related to differences in the rate of peat decomposition. Peat decomposition in drained sites is much faster in southern compared with northern locations (Hiraishi et al., 2014), suggesting that increasing trends of nutrients in waters from drained peatland forests may most likely be found in southern locations. Forests are also much denser and taller in southern boreal regions than in northern, and thus, it is likely that forests contribute more to litter inputs and evapotranspiration in the southern locations.

The aim of this study was to increase the understanding of the long-term temporal trends of nutrient concentrations in waters discharging from drained boreal peatland forests. To do that, we gathered water quality data from 18 forestry-drained and 11 undrained peatlands, and studied the factors contributing to their long-term (10-29 years) nitrogen and phosphorus concentration trends. Our hypothesis is that increasing concentration trends occur mostly in southern latitudes, where higher temperatures increase peat decomposition and tree growth more than in the north.

\section{Material and Methods}

\subsection{Study Sites}

We studied the long-term (10-29 years) temporal trends of total nitrogen (TN) and total phosphorus (TP) concentrations from 29 boreal forest catchments, 18 of which were managed using typical even-aged rotation-forestry methods and 11 sites 
Table 1 Basic information on the studied catchment areas

\begin{tabular}{|c|c|c|c|c|c|c|c|c|}
\hline \multirow[t]{2}{*}{ Area } & \multicolumn{2}{|l|}{ Location } & \multirow{2}{*}{$\begin{array}{l}\text { Area } \\
\text { ha }\end{array}$} & \multirow{2}{*}{$\begin{array}{l}\text { Peatlands, } \\
\%\end{array}$} & \multirow{2}{*}{$\begin{array}{l}\text { Drained, } \\
\%\end{array}$} & \multirow[t]{2}{*}{ Tsum } & \multirow{2}{*}{$\begin{array}{l}\text { Stand V, } \\
\mathrm{m}^{3} \mathrm{ha}^{-1}\end{array}$} & \multirow[t]{2}{*}{ Monit. years } \\
\hline & $\mathrm{N}$ & $\mathrm{E}$ & & & & & & \\
\hline \multicolumn{9}{|l|}{ Drained } \\
\hline Latokartano & 6724116 & 452612 & 12 & 20 & 20 & 1440 & 233 & 2007-2016 \\
\hline Huhtisuonoja & 6806314 & 588124 & 494 & 47 & 47 & 1385 & 145 & 1990-2018 \\
\hline Jylisjärvi & 6765327 & 381359 & 12 & 30 & 30 & 1350 & 142 & 1994-2005 \\
\hline \multirow[t]{2}{*}{ Paunulanpuro } & 6839687 & 359364 & 153 & 10 & 10 & 1340 & 130 & 1991-2001, \\
\hline & & & & & & & & 2014-2018 \\
\hline \multirow[t]{2}{*}{ Ruokesuo } & 6826042 & 313542 & 44 & 27 & 25 & 1360 & 145 & 1993-2001, \\
\hline & & & & & & & & 2014-2015 \\
\hline Heinäjoki & 6893873 & 416863 & 950 & 10 & 10 & 1260 & 120 & $1990-2004$ \\
\hline \multirow[t]{2}{*}{ Katajaluoma } & 6847801 & 277094 & 1120 & 37 & 37 & 1250 & 93 & 1991-1994, \\
\hline & & & & & & & & 2014-2018 \\
\hline Kesselinpuro & 6950600 & 604008 & 2170 & 50 & 34 & 1250 & 143 & $1990-2018$ \\
\hline Pehkusuonoja & 6863172 & 327123 & 25 & 18 & 11 & 1220 & 160 & $1993-2005$ \\
\hline \multirow[t]{2}{*}{ Pahkapuro } & 7037858 & 372575 & 2344 & 45 & 27 & 1075 & 63 & 1991-1999, \\
\hline & & & & & & & & 2014-2018 \\
\hline Myllypuro & 7173109 & 578316 & 1053 & 25 & 15 & 900 & 85 & $1990-2018$ \\
\hline Joutenpuro & 7203298 & 574992 & 351 & 52 & 48 & 960 & 79 & $1990-2008$ \\
\hline Kotioja & 7336762 & 460398 & 1719 & 54 & 27 & 880 & 50 & $1990-2014$ \\
\hline Vähä-Askanjoki & 7380982 & 529867 & 1640 & 21 & 10 & 880 & 50 & $1990-2018$ \\
\hline Ylijoki & 7339670 & 462280 & 5650 & 53 & 29 & 880 & 42 & $1990-2018$ \\
\hline Krycklan & 7146659 & 150158 & 6790 & 21 & 13 & 870 & 106 & $1993-2019$ \\
\hline \multirow[t]{2}{*}{ Vääräjoki } & 7311871 & 599361 & 1900 & 42 & 4 & 820 & 49 & 1991-2000, \\
\hline & & & & & & & & 2014-2018 \\
\hline Lompolojängänoja & 7545547 & 383057 & 514 & 24 & 10 & 720 & 45 & $2007-2018$ \\
\hline \multicolumn{9}{|l|}{ Undrained } \\
\hline Punassuo & 6682146 & 280286 & 220 & 90 & 0 & 1475 & 40 & 2004-2014 \\
\hline Lakkasuo 3 & 6853910 & 358167 & 15 & 55 & 0 & 1240 & 107 & $1992-2016$ \\
\hline Lakkasuo 7 & 6853755 & 358341 & 10 & 100 & 0 & 1240 & 18 & $1992-2015$ \\
\hline Korsukorpi & 7084605 & 581280 & 69 & 56 & 0 & 1100 & 61 & $1992-2013$ \\
\hline Liuhapuro & 7075576 & 573066 & 164 & 48 & 0 & 1090 & 101 & $1990-2018$ \\
\hline Välipuro & 7083611 & 581404 & 77 & 56 & 0 & 1090 & 106 & $1990-2013$ \\
\hline Kangaslampi & 7082638 & 596709 & 29 & 9 & 0 & 1050 & 132 & $1992-2013$ \\
\hline Porkkavaara & 7083270 & 606061 & 72 & 16 & 0 & 1050 & 160 & $1992-2018$ \\
\hline Kelopuro & 7008998 & 685905 & 137 & 47 & 0 & 1040 & 100 & $1990-2018$ \\
\hline Runkaus 6 & 7324360 & 429812 & 3800 & 71 & 1 & 900 & 26 & $1996-2017$ \\
\hline Laanioja & 7587750 & 515971 & 1360 & 4 & 4 & 690 & 41 & $1990-2018$ \\
\hline
\end{tabular}


Table 1 (continued)

Peatlands $\%=$ proportion of peatlands in the catchment area; drained $\%=$ proportion of drained peatlands in the catchment area; Tsum $=$ temperature sum (degree days, $\geq 5^{\circ} \mathrm{C}$ ); stand $\mathrm{V}=\operatorname{stand}$ volume in the catchment area $\left(\mathrm{m}^{3} \mathrm{ha}^{-1}\right)$. Stand volumes were estimated by either measuring tree attributes in conventional field plots or utilizing the open database of the Multi-source National Forest Inventory of Finland (Mäkisara et al., 2016)

were catchments dominated by undrained peatlands (Table 1). The Krycklan catchment is in Sweden; the other catchments are in Finland. Temporal trends in TN and TP concentrations from some of the catchments included in this study have been presented earlier (e.g., Lepistö et al., 2021), but this study utilizes a more extensive data set than previous trend analyses. The Latokartano catchment is a control catchment from the study by Kaila et al. (2015), the Krycklan catchment study data can be found on their data service webpage (https://www.slu.se/Krycklan), and the other data were derived from the national database maintained by the Finnish Environment Institute (https://www.syke.fi/en-US/Open_information/Open_ web_services/Environmental_data_API) and the Natural Resources Institute Finland (https://metsainfo. luke.fi/fi/vesistokuormitukset).

The annual climatic cycle in the study region includes four distinct seasons. The winter period (December-March) is characterized by freezing temperatures and a snow cover ranging from about 20 to $120 \mathrm{~cm}$. The snowmelt period typically starts in late April or early May, and after 2 or 3 weeks, the snowpack and the frozen ground have melted. Summer (June-August) is characterized by a daily mean temperature of about $17{ }^{\circ} \mathrm{C}$ in the southern part and $13{ }^{\circ} \mathrm{C}$ in the northernmost part of the region. During autumn (September-November), the daily temperatures gradually decrease from 10 to $15{ }^{\circ} \mathrm{C}$ to values below zero, and late in the end of the period, the ground and surface water bodies start to freeze. The mean annual precipitation is $550-700 \mathrm{~mm}$, 200-300 mm of which falls as snow.

Our principal selection criteria of the sites were that the site should have been monitored for at least 10 years and that no forest operations covering large parts of the catchment $(>10 \%)$ should have been executed between 1980 and 2019, that is, during the study period and 10 years before it (see also Sarkkola et al., 2009; Nieminen et al., 2017, 2018). The latter selection criterion was to enable the long-term trends from managed catchments to be studied without the recurrent decreasing and increasing concentration periods caused by successive forestry operations (see also Nieminen et al., 2018).

The catchments are typical conifer-dominated forest areas in Nordic countries, where Norway spruce (Picea abies (L.) Karsten) dominates the most fertile sites, and Scots pine (Pinus sylvestris L.) dominates the low-fertile mineral soils and tree-covered bogs. Silver (Betula pendula Roth) and downy birch (Betula pubescens Ehrh.) are generally only found as mixed species, the first in mineral soils and the latter in peatlands. Peatlands cover $4-100 \%$ of the catchment areas in the undrained sites, and $10-54 \%$ in the drained sites (Table 1). Drained peatlands cover $4-48 \%$ of the areas of drained catchments. Agricultural areas are almost non-existent, except at Heinäjoki, where they cover about $8 \%$ of the catchment area. The tree stand volume in the study region has increased by almost $70 \%$ over the past few decades, from about 1500 million $\mathrm{m}^{3}$ in the 1970 s to about 2500 million $\mathrm{m}^{3}$ at the end of the 2010s in Finland (Luke Forest Statistics, 2021). The stand volume in the catchments varies from 42 to $233 \mathrm{~m}^{3} \mathrm{ha}^{-1}$ in the drained catchments, and between 18 and $160 \mathrm{~m}^{3} \mathrm{ha}^{-1}$ in the undrained catchments. Temperature sum (degree days (d.d.), $\geq 5{ }^{\circ} \mathrm{C}$ ) varies from 690 d.d. in the northernmost to 1475 d.d. in the southernmost site (Table 1).

\subsection{Sampling and Analyses}

The water samples were collected by focusing on the periods with high flows, which are in the study region the spring snowmelt period and the autumn heavy rainfalls. The samples were collected from an outflow ditch or stream draining each catchment, either from the flow of a V-notch weir or a discharge pipe of a soil embankment (Latokartano). On average, 9 samples were taken per year. Mid-summer (July-August) periods are often missing because of no or minor runoff. Concentrations of TN and TP were analyzed either colorimetrically after oxidation with $\mathrm{K}_{2} \mathrm{~S}_{2} \mathrm{O}_{8}$ (Vesihallinnon analyysimenetelmät, 1981) or TN using flow injection analysis (Tecaton FIA) and the NPOC method. 


\subsection{Calculations}

Linear trends in TN and TP concentrations ( $\mathrm{mg} \mathrm{l}^{-1}$ ) in each of the 29 catchments were calculated using the non-parametric Mann-Kendall test (Gilbert, 1996), which has been widely used in trend analyses. The Kendall test is suitable because it is robust to outliers, missing data, and non-normality of the time series. The slopes of the trends express the median change in the time series and were calculated using the Sen slope $(S)$ estimation method. The tests were performed in R (R Core Team 2019) using the Kendall and trend packages (McLeod, 2011).

Ordinary regression analysis (OLS) was used to identify the factors behind the variation in trends (i.e., Sen's slope estimates). The tested explanatory factors in the regression models were (i) catchment area (ha), (ii) percentage of undrained peatlands in the catchments (\%), (iii) percentage of drained peatlands in the catchments (\%), (iv) temperature sum as the parameter for site altitudinal and latitudinal location (degree days (d.d.), $>5{ }^{\circ} \mathrm{C}$ ), and (v) average tree stand volume in the catchments $\left(\mathrm{m}^{3} \mathrm{ha}^{-1}\right)$.

\section{Results}

Average TN concentrations $( \pm \mathrm{SD})$ in the catchments with drained peatlands were $506( \pm 232) \mu \mathrm{g} \mathrm{l^{-1 }}$, and TP concentrations $25( \pm 16) \mu \mathrm{g} \mathrm{l}^{-1}$. TN and TP concentrations in the catchments with undrained sites were $394( \pm 145)$ and $11( \pm 6) \mu g l^{-1}$, respectively.

$\mathrm{TN}$ concentrations in waters discharging from the 11 undrained peatlands increased significantly in two sites and decreased significantly in two sites, while TP concentrations increased in three sites and decreased in one site (Table 2). Among the 18 drained sites, TN concentrations increased significantly from eight sites and decreased from two sites, while TP concentrations increased from three sites and decreased from five sites.

The TN trends (Sen slope estimates) correlated positively with temperature sum and tree stand volume in the catchments, and slightly negatively with the area of the catchment (Fig. 1). Peatland area or drained peatland area did not correlate with $\mathrm{TN}$ trends. None of the explanatory factors were in clear correlation with the temporal trends in $\mathrm{TP}$ concentrations.
Table 2 Observed trends (Sen's slope estimates) in TN and TP concentrations in waters discharging from the studied catchments

\begin{tabular}{|c|c|c|c|c|}
\hline Area & TN-trend & & TP-trend & \\
\hline \multicolumn{5}{|l|}{ Drained } \\
\hline Latokartano & 32.51 & $*$ & 3.39 & \\
\hline Huhtisuonoja & 4.45 & & -0.93 & $* * *$ \\
\hline Jylisjärvi & 10.55 & & 0.04 & \\
\hline Paunulanpuro & 5.03 & $* *$ & 0.26 & $*$ \\
\hline Heinäjoki & 7.58 & $*$ & -0.40 & \\
\hline Ruokesuo & 1.82 & $* * *$ & 0.00 & \\
\hline Katajaluoma & 10.20 & $*$ & 0.40 & $*$ \\
\hline Kesselinpuro & 2.78 & & -0.74 & $* * *$ \\
\hline Pehkusuonoja & 18.30 & $* *$ & 0.56 & \\
\hline Pahkapuro & 0.00 & & -0.26 & $* *$ \\
\hline Myllypuro & 1.21 & & -0.22 & $*$ \\
\hline Joutenpuro & 8.97 & $*$ & 0.04 & \\
\hline Kotioja & 5.32 & $* * *$ & 0.17 & $*$ \\
\hline Vähä-Askanjoki & -0.45 & & -0.09 & \\
\hline Ylijoki & -0.90 & & -0.02 & \\
\hline Krycklan & -10.09 & $*$ & -4.55 & $* * *$ \\
\hline Vääräjoki & -1.90 & $*$ & 0.00 & \\
\hline Lompolojängänoja & 0.11 & & 0.17 & \\
\hline \multicolumn{5}{|l|}{ Undrained } \\
\hline Punassuo & 1.67 & & 0.00 & \\
\hline Lakkasuo 3 & 6.78 & $* *$ & 0.13 & $*$ \\
\hline Lakkasuo 7 & 6.72 & & 0.20 & $* *$ \\
\hline Korsukorpi & -4.10 & $* *$ & 0.25 & $* *$ \\
\hline Liuhapuro & 1.75 & $*$ & -0.01 & \\
\hline Välipuro & 0.97 & & -0.07 & \\
\hline Kangaslampi & 0.55 & & -0.12 & $* *$ \\
\hline Porkkavaara & 0.63 & & 0.00 & \\
\hline Kelopuro & -0.23 & & -0.01 & \\
\hline Runkaus 6 & 0.87 & & 0.09 & \\
\hline Laanioja & -1.05 & $* *$ & -0.01 & \\
\hline
\end{tabular}

*Significant at $p<0.10$ level, **significant at $p<0.01$ level, $* * *$ significant at $p<0.001$ level

\section{Discussion}

The results of the study supported our hypothesis in that the trends in nitrogen concentrations correlated positively with factors related to latitude, i.e., the volume of the tree stand in the catchments and the temperature sum of the study site. A few previous studies have indicated that the general increase in forest cover and biomass in northern latitudes during recent decades ("greening effect") may be one factor behind 

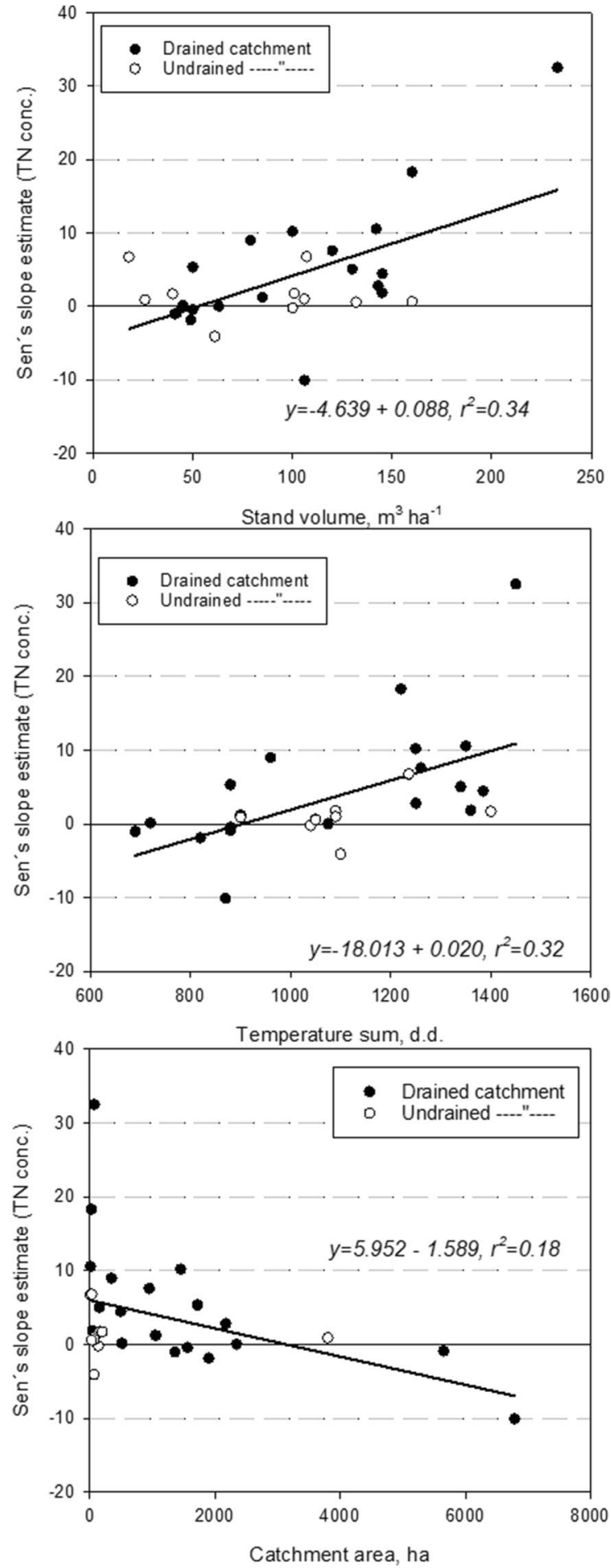

Fig. 1 The relationship between tree stand volume $\left(\mathrm{m}^{3} \mathrm{ha}^{-1}\right)$, temperature sum (d.d., $>5{ }^{\circ} \mathrm{C}$ ), and catchment area (ha) in the 29 catchments included in the study and TN concentration trends (Sen's slope estimates) in waters discharging from the catchments increasing organic carbon concentrations in forested streams (Finstad et al., 2016; Nieminen et al., 2021; Škerlep et al., 2019), but ours is the first study showing that the trends in nitrogen concentrations may also correlate positively with the increase in forest biomass. Tree stand volume and latitude are positively correlated; tree stands with higher volume are found in southern rather than northern locations in the Nordic region (Henttonen et al., 2020), thus complicating the interpretation of the results. That is, it is unclear whether the increasing trends are primarily related to tree physicochemical processes, such as evapotranspiration and root exudates, or site locationrelated factors, such as temperature.

None of the explanatory factors we tested correlated with the trends in TP concentrations. This may be because TP concentrations correlate with factors not studied here, such as rates of weathering of the parent material in the catchments or past fertilization activity. Fertilization of drained peatlands was very active in Finland during the 1960s to 1980s, which may have had long-term effects on phosphorus exports (Nieminen et al., 2018). More sites indicated decreasing rather than increasing trends for $\mathrm{TP}$, which may be because the waters are still recovering from the effects of past fertilization (Finér et al., 2021; Nieminen et al., 2018).

Increasing $\mathrm{TN}$ concentration trends in the largevolume tree stands of the south may be due to several reasons. One mechanism by which tree cover may have a positive effect on the TN concentrations is the effect of tree canopy on dry deposition capture of nitrogen (Sievering et al., 2007). Forest-covered areas capture more dry deposition than open areas, and nitrogen deposition is higher in boreal regions in the south than in the north (Lövblad et al., 1992); together, these two factors may increase TN concentrations in surface waters particularly in mature tree stands in the south. The effect of tree stand on TN concentrations may also be due to increased nitrogen-rich tree litter input into the soil (Straková et al., 2010, 2012).

In drained peatland forests, one mechanism by which tree cover contributes to increasing TN concentrations may also be the increasing evapotranspiration along with maturing of the tree stands (Sarkkola et al., 2010), resulting in lower water levels and thicker oxidized peat layers in drained and densely forested peatlands compared with sparsely covered 
or open areas. However, there was no correlation between drained area in the catchments and increasing TN concentrations in our data. Thus, the correlation between tree stand volume and increasing TN concentrations may not be specific to drained peatlands but may also apply to mineral soil forests.

Increasing $\mathrm{TN}$ trends primarily in the south and large-volume tree stands are worrying from the viewpoint of the future evolution of water quality in forested catchments. Future climatic conditions in the north may become similar as they are now in the south (Ruosteenoja et al., 2016), suggesting that TN concentrations in waters from forested catchments may begin to increase also in the north. The generally accepted policy in northern countries is to increase afforestation and tree growth in order to increase carbon sequestration in forest biomass and replace fossil fuels with renewable materials. Based on the results of this paper and some earlier studies (Finstad et al., 2016; Nieminen et al., 2021), this well-meaning policy may have the negative side effect of increasing carbon and nitrogen concentrations in waters discharging from forested catchments. It is thus of utmost importance to carry on monitoring water quality from these and other forested catchments in order to assess if the observed positive "forest biomass-concentration trend" relationship for TN is due to historic reasons or if increase in forest biomass will also contribute to nitrogen concentrations in the future.

It should be noted here, however, that although increasing stand volumes can result in increasing nitrogen and carbon concentrations in waters from forested catchments, water flows may reduce concurrently due to higher evapotranspiration of the larger tree stands (Sarkkola et al., 2010). Thus, the overall result of the "greening effect" in high latitudes may not be increasing carbon and nitrogen exports $(\mathrm{kg}$ $\mathrm{ha}^{-1}$ year $^{-1}$ ) to water courses, but less water with higher nitrogen and carbon concentrations in receiving lakes and streams particularly during growing season. The studies in forested areas should thus perhaps focus more on water quality issues than attempt to produce estimates on nutrient and carbon exports induced by forestry (e.g., Finér et al., 2021). Less water with poorer quality in forested lakes and streams particularly during summer seasons would significantly reduce their value for recreational purposes, and plausibly also severely decrease their aquatic biodiversity (Kritzberg et al., 2020).
In conclusion, our study indicated that there have been very variable trends in nitrogen and phosphorus concentrations in waters from forested catchments in the Nordic region over the past decades. The mechanisms behind varying phosphorus trends remained largely unexplained, but the trends in nitrogen concentrations were positively correlated with tree stand volume and temperature sum. This study thus indicates that the general increase in tree cover and biomass in forested catchments in the Nordic regions over the past decades may not only have increased carbon concentrations in forested streams and lakes (Finstad et al., 2016; Nieminen et al., 2021), but also nitrogen concentrations. A positive correlation of increasing nitrogen concentrations with temperature sum raises concerns of the future evolution of nitrogen exports under a warming climate, as does also the correlation with tree stand volume due to the generally accepted policy of tackling climatic crisis by boosting tree growth. However, future research is still needed to assess which are the actual processes related to stand volume and temperature sum that contribute to increasing nitrogen concentrations.

Funding Open access funding provided by Natural Resources Institute Finland (LUKE).

Data Availability The data sets generated during and/or analyzed during the current study are available from the corresponding author on reasonable request.

\section{Declarations}

Conflict of Interest The authors declare no competing interests.

Open Access This article is licensed under a Creative Commons Attribution 4.0 International License, which permits use, sharing, adaptation, distribution and reproduction in any medium or format, as long as you give appropriate credit to the original author(s) and the source, provide a link to the Creative Commons licence, and indicate if changes were made. The images or other third party material in this article are included in the article's Creative Commons licence, unless indicated otherwise in a credit line to the material. If material is not included in the article's Creative Commons licence and your intended use is not permitted by statutory regulation or exceeds the permitted use, you will need to obtain permission directly from the copyright holder. To view a copy of this licence, visit http://creativecommons.org/licenses/by/4.0/. 


\section{References}

Erlandsson, M., Buffam, I., Fölster, J., Laudon, H., Temnerud, J., Weyhenmeyer, G. A., \& Bishop, K. (2008). Thirty-five years of synchrony in the organic matter concentrations of Swedish rivers explained by variation in flow and sulphate. Global Change Biology, 14, 1191-1198. https://doi.org/10.1111/j.1365-2486. 2008.01551.x

Finér, L., Lepistö, A., Karlsson, K., Räike, A., Härkönen, L., Huttunen, M., Joensuu, S., Kortelainen, P., Mattsson, T., Piirainen, S., Sallantaus, T., Sarkkola, S., Tattari, S., \& Ukonmaanaho, L. (2021). Drainage for forestry increases $\mathrm{N}, \mathrm{P}$ and TOC export to boreal surface waters. Science of the Total Environment, 762, 1440982. https://doi.org/10. 1016/j.scitotenv.2020.144098

Finér, L., Mattsson, T., Joensuu, S., Koivusalo, H., Laurén, A., Makkonen, T., Nieminen, M., Tattari, S., Ahti, E., Kortelainen, P., Koskiaho, J., Leinonen, A., Nevalainen, R., Piirainen, S., Saarelainen, J., Sarkkola, S., \& Vuollekoski, M. (2010). Metsäisten valuma-alueiden vesistökuormituksen laskenta (A method for calculating nitrogen, phosphorus and sediment load from forested catchments). Suomen ympäristö 10/2010. 33 p.

Finstad, A., Andersen, T., Larsen, S., Tominaga, K., Blumentrath, S., de Wit, H. A., Tømmervik, H., \& Hessen, D. O. (2016). From greening to browning: Catchment vegetation development and reduced S-deposition promote organic carbon load on decadal time scales in Nordic lakes. Nature Scientific Reports, 6, 31944. https://doi.org/10.1038/srep3 1944

Gilbert, R.O. (1996). Statistical methods for environmental pollution monitoring. New York: Van Nostrand Reinhold, 1996, $320 \mathrm{pp}$.

Heikurainen, L., Kenttämies, K., \& Laine, J. (1978). The environmental effects of forest drainage. Suo, 29, 49-58.

Henttonen, H. M., Nöjd, P., Suvanto, S., Heikkinen, J., \& Mäkinen, H. (2020). Size-class structure of the forests of Finland during 1921-2013: A recovery from centuries of exploitation, guided by forest policies. European Journal of Forest Research, 139, 279-293. https://doi.org/10.1007/ s10342-019-01241-y

Hiraishi, T., Krug, T., Tanabe, K., Srivastava, N., Baasansuren, J., Fukuda, M. \& Troxler, T.G. (Eds.) (2014). 2013 supplement to the 2006 IPCC guidelines for national greenhouse gas inventories: Wetlands. IPCC, Switzerland. https://www.ipcc-nggip.iges.or.jp/public/wetlands/index. html

Kaila, A., Laurén, A., Sarkkola, S., Koivusalo, H., Ukonmaanaho, L., Xiao, L., Asam, Z., O’Driscoll, C., \& Nieminen, M. (2015). Effect of clear-felling and harvest residue removal on nitrogen and phosphorus export from drained Norway spruce mires in southern Finland. Boreal Environment Research, 20, 693-706.

Kritzberg, E. S., Hasselquist, E. M., Škerlep, M., Löfgren, S., Olsson, O., Stadmark, J., Valinia, S., Hansson, L.-A., \& Laudon, H. (2020). Browning of freshwaters: Consequences to ecosystem services, underlying drivers, and potential mitigation measures. Ambio, 49, 375-390. https://doi.org/10.1007/s13280-019-01227-5
Laudon, H., Buttle, J., Carey, S. K., McDonnell, J., McGuire, K., Seibert, J., Shanley, J., Soulsby, C., \& Tetzlaff, D. (2012). Cross-regional prediction of long-term trajectory of stream water DOC response to climate change. Geophysical Research Letters, 39(18), L18404. https://doi.org/ 10.1029/2012GL053033

Laurén, A., Palviainen, M., Launiainen, S., Leppä, K., Stenberg, L., Urzainki, I., Nieminen, M., Laiho, R., \& Hökkä, H. (2021). Drainage and stand growth response in peatland forests - Description, testing, and application of mechanistic peatland simulator SUSI. Forests, 12, 293. https://doi.org/10.3390/f12030293 23 p.

Lepistö, A., Räike, A., Sallantaus, T., Finér, L. (2021). Increases in organic carbon and nitrogen concentrations in boreal forested catchments - Changes driven by climate and deposition. Science of the Total Environment (in press.).

Lövblad, G., Amann, M., Andersen, B., Hovmand, M., Joffre, S., \& Pedersen, U. (1992). Deposition of sulfur and nitrogen in the Nordic countries: Present and future. Ambio, 21(5), 339-347.

Luke Forest Statistics (2021). Database of Finnish Forest Statistics. Natural Resources Institute Finland (Luke). http:// statdb.luke.fi/PXWeb/pxweb/en/LUKE/?rxid=dc711a9ede6d-454b-82c2-74ff79a3a5e0

Mäkisara, K., Katila, M., Peräsaari, J., \& Tomppo, E. (2016). The multi-source national forest inventory of Finland Methods and results 2013. Natural Resources and Bioeconomy Studies 10/2016, 215 p.

McLeod, A. I. (2011). Kendall: Kendall rank correlation and Mann-Kendall trend test. $\mathrm{R}$ package version 2.2. https:// CRAN.R-project.org/package $=$ Kendall

Monteith, D. T., Stoddard, J. L., Evans, C. D., de Wit, H. A., Forsius, M., Høgåsen, T., Wilander, A., Skjelkvåle, B. L., Jeffries, D. S., Vuorenmaa, J., Keller, B., Kopácek, J., \& Vesely, J. (2007). Dissolved organic carbon trends resulting from changes in atmospheric deposition chemistry. Nature, 450, 537-541. https://doi.org/10.1038/natur e06316

Nieminen, M., Sallantaus, T., Ukonmaanaho, L., Nieminen, T. M., \& Sarkkola, S. (2017). Nitrogen and phosphorus concentrations in discharge from drained peatland forests are increasing. Science of the Total Environment, 609, 974981. https://doi.org/10.1016/j.scitotenv.2017.07.210

Nieminen, M., Sarkkola, S., Haahti, K., Sallantaus, S., Koskinen, M., \& Ojanen, P. (2020). Metsäojitettujen soiden typpi- ja fosforikuormitus. Summary: Forestry on drained peatlands as a source of surface water nitrogen and phosphorus in Finland. Suo, 71, 1-13. ISSN 0039-5471.

Nieminen, M., Sarkkola, S., Sallantaus, T., Hasselquist, E. M., \& Laudon, H. (2021). Peatland drainage - A missing link behind increasing TOC concentrations in waters from high latitude forest catchments? Science of the Total Environment, 774(18), 145150. https://doi.org/10.1016/j.scito tenv.2021.145150

Nieminen, M., Sarkkola, S., Hellsten, S., Marttila, H., Piirainen, S., Sallantaus, T., \& Lepistö, A. (2018). Increasing and decreasing nitrogen and phosphorus trends in runoff from drained peatland forests-Is there a legacy effect of drainage or not? Water, Air, and Soil Pollution 229(8). https://doi.org/10.1007/s11270-018-3945-4 
Paavilainen, E., Päivänen, J., 1995. Peatland forestry - Ecology and principles. Ecological Studies 111. Springer-Verlag, Berlin, Heidelberg, New York.

Räike, A., Taskinen, A., \& Knuuttila, S. (2019). Nutrient export from Finnish rivers into the Baltic Sea has not decreased despite water protection measures. Ambio, 49, 460-474. https://doi.org/10.1007/s13280-019-01217-7

Ruosteenoja, K., Jylhä, K., \& Kämäräinen, M. (2016). Climate projections for Finland under the RCP forcing scenarios. Geophysica, 51(1), 17-50.

Sarkkola, S., Hökkä, H., Koivusalo, H., Nieminen, M., Ahti, E., Päivänen, J., \& Laine, J. (2010). Role of tree stand evapotranspiration in maintaining satisfactory drainage conditions in drained peatlands. Canadian Journal of Forest Research, 40, 1485-1496. https://doi.org/10.1139/ X10-084

Sarkkola, S., Koivusalo, H., Laurén, A., Kortelainen, P., Mattsson, T., Palviainen, M., Piirainen, S., Starr, M., \& Finér, L. (2009). Trends in hydrometeorological conditions and stream water organic carbon in boreal forested catchments. Science of the Total Environment, 408(1), 92-101. https://doi.org/10.1016/j.scitotenv.2009.09.008

Sievering, H., Tomaszewski, T., \& Torizzo, J. (2007). Canopy uptake of atmospheric $\mathrm{N}$ deposition at a conifer forest: Part I - Canopy $\mathrm{N}$ budget, photosynthetic efficiency and net ecosystem exchange. Tellus B: Chemical and Physical Meteorology, 59(3), 483-492. https://doi.org/10.1111/j. 1600-0889.2007.00264.x
Škerlep, M., Steiner, E., Axelsson, A.-L., \& Kritzberg, E. S. (2019). Afforestation driving long-term surface water browning. Global Change Biology, 26(3), 1390-1399. https://doi.org/10.1111/gcb.14891

Straková, P., Anttila, J., Spetz, P., Kitunen, V., Tapanila, T., \& Laiho, R. (2010). Litter quality and its response to water level drawdown in boreal peatlands at plant species and community level. Plant and Soil, 335, 501-520. https:// doi.org/10.1007/s11104-010-0447-6

Straková, P., Penttilä, T., Laine, J., \& Laiho, R. (2012). Disentangling direct and indirect effects of water table drawdown on above- and belowground plant litter decomposition: Consequences for accumulation of organic matter in boreal peatlands. Global Change Biology, 18, 322-335. https://doi.org/10.1111/j.1365-2486.2011.02503.x

Vesihallinnon analyysimenetelmät. (1981). The analysis methods of water samples in Finnish Environment Institute (p. 136). Vesihallitus.

Publisher's Note Springer Nature remains neutral with regard to jurisdictional claims in published maps and institutional affiliations. 